\title{
High bacterial carbon demand and low growth efficiency at a tropical hypereutrophic estuary: importance of dissolved organic matter remineralization
}

\author{
Mariana Guenther ${ }^{*}$, Eliane Gonzalez-Rodriguez ${ }^{2}$,Manuel Flores-Montes ${ }^{3}$, Moacyr Araújo ${ }^{3}$, Sigrid \\ Neumann-Leitão ${ }^{3}$
}

\author{
${ }^{1}$ Instituto de Ciências Biológicas, Universidade de Pernambuco \\ (Rua Arnóbio Marques, 310 - Santo Amaro - Recife - Pernambuco, 50100-130 - Brazil) \\ ${ }^{2}$ Instituto de Estudos do Mar Almirante Paulo Moreira \\ (Rua Kioto, 253 - Praia dos Anjos, Arraial do Cabo - RJ, 28930-000 - Brazil) \\ ${ }^{3}$ Departamento de Oceanografia, Universidade Federal de Pernambuco \\ (Av. Prof. Moraes Rego, 1235 - Cidade Universitária, Recife - PE - 50670-901 - Brazil) \\ *Corresponding author: mariana.guenther@upe.br
}

\section{Abstract}

Simultaneous measurements of bacterioplankton production (BP) and respiration (BR) are imperative to understand the magnitude of carbon cycle in the lower trophic levels of the aquatic systems, but are still scarce in the tropics. The present study was performed in a highly productive estuary (Recife harbor, $08^{\circ} 03^{\prime} \mathrm{S}$; $34^{\circ} 52^{\prime} \mathrm{W}$, NE Brazil) where bacterial carbon demand $(\mathrm{BCD}=\mathrm{BP}+\mathrm{BR})$ and growth efficiency $(\mathrm{BGE}=\mathrm{BP} / \mathrm{BCD})$ were evaluated in order to estimate the major role of bacterioplankton: source or sink of organic carbon. In spite of the high BP rates (0.03-0.4 $\left.\mu \mathrm{MC} \mathrm{h}^{-1}\right)$, the extremely high BR rates $\left(0.5-4.1 \mu \mathrm{MC} \mathrm{h}^{-1}\right)$ led to low BGE (0.02-0.29), possibly due to the high temperatures $\left(>25^{\circ} \mathrm{C}\right)$ and strong inorganic nitrogen limitation (N:P ratios) The high $\mathrm{BCD}$ and low $\mathrm{BGE}$ indicate the major role of bacterioplankton as dissolved organic matter remineralizers, fueling the primary productivity of the system. These findings contradict what could be expected from studies in highly productive temperate estuaries (where BGE is usually $>0.30$ ) and highlight the importance of increasing in situ BP and BR estimates in tropical estuarine systems in order to better understand the role of these systems in global carbon cycling.

Descriptors: Bacterioplankton, Bacterial production, Bacterial respiration, Microbial loop, BCD, BGE.

\section{Resumo}

Medidas simultâneas de produção (PB) e respiração bacterianas (RB) são indispensáveis para o entendimento da magnitude do ciclo do carbono nos níveis tróficos mais basais dos sistemas aquáticos, mas são ainda escassas nos trópicos. O presente estudo foi realizado em um estuário extremamente produtivo (Porto do Recife, $08^{\circ} 03^{\prime} \mathrm{S}$; $34^{\circ} 52^{\prime} \mathrm{W}$, NE do Brasil), onde a demanda bacteriana por carbono $(\mathrm{DBC}=\mathrm{PB}+\mathrm{RB})$ e a eficiência de crescimento bacteriano $(\mathrm{ECB}=\mathrm{PB} / \mathrm{DBC})$ foram determinadas para estimar o principal papel do bacterioplâncton: fonte ou captador de carbono orgânico. Apesar das altas taxas de PB $\left(0.03-0.4 \mu \mathrm{MC} \mathrm{h}^{-1}\right)$, as taxas extremas de RB (0.5-4.1 $\left.\mu \mathrm{MC} \mathrm{h}^{-1}\right)$ levaram a baixa ECB (0.02$0.29)$, provavelmente devido às altas temperaturas $\left(>25^{\circ} \mathrm{C}\right)$ e forte limitação por nitrogênio inorgânico (razão N:P) A alta DBC e a baixa ECB indicam que o bacterioplâncton esteja atuando principalmente como remineralizador da matéria orgânica dissolvida, alimentando a produção primaria do sistema. Esses resultados contradizem o que seria esperado baseado em estudos conduzidos em estuários eutróficos temperados (onde geralmente ECB > 0.30) e apontam para a importância de se aumentar estimativas in situ de PB e RB em sistemas estuarinos tropicais a fim de se promover um melhor entendimento do papel desses sistemas na ciclagem de carbono global.

Descritores: Bacterioplâncton, Produção bacteriana, Respiração bacteriana, Alça microbiana, DBC, ECB. 


\section{INTRODUCTION}

Bacterioplankton play multiple roles in aquatic systems, converting high amounts of allochthonous and autochthonous organic material into nutrients (organic remineralization) and biomass (organic production). Understanding the extent and the regulating factors of each of these bacterial metabolic pathways is thus imperative to comprehend the carbon cycle in those systems. The amount of carbon incorporated by bacterioplankton is partitioned into growth (anabolism) and maintenance processes (catabolism). The bacterial carbon demand (BCD) is thus the sum of biomass produced (=bacterial production: $\mathrm{BP}$ ) and the energetic loss (=bacterial respiration: BR). The efficiency to which the carbon incorporated is converted into biomass, i.e., the bacterial growth efficiency (BGE) is thus estimated as BP/BCD (DEL GIORGIO; COLE, 1998).

Bacterial carbon consumption has been usually derived from bacterial production rates assuming constant growth efficiencies (GASOL et al., 2008). Nevertheless, several studies showed a great spatial and temporal variability in BGE within and among systems, due to several abiotic and biotic factors like temperature, inorganic nutrients availability, dissolved organic matter (DOM) quality, light incidence and grazing pressure (APPLE; DEL GIORGIO, 2007; APPLE et al., 2006; ASMALA et al., 2014; BERGGREN et al., 2010; CORY et al., 2010; RAM et al., 2003). The need for simultaneous in situ estimates of bacterial production and respiration rates became thus imperative to accurately evaluate the bacterial carbon metabolism in the aquatic systems and understand its regulation.

Estuarine systems are increasingly subject to eutrophication processes due to the rapid population growth and consequent density increase along the coast (DAY et al., 2013). The high and continuous input of allochthonous nutrients and organic material from the surrounding lands and the domestic sewage leads to high phytoplankton and bacterial growth (BARRERA-ALBA et al., 2008; GAULKE et al., 2010; GUENTHER; VALENTIN, 2008b; MORTAZAVI et al.; 2012; SCHUMANN et al., 2003; YUAN et al., 2010). However, most of estuarine BGE in situ estimates were performed in temperate zones, with few exceptions on the tropics (GUENTHER et al., 2008a; LEE et al., 2009; RAM et al., 2003; RAM et al., 2007).
In the most comprehensive review on BGE to date, DEL GIORGIO and COLE (1998) verified a direct correlation between BGE and the trophic status of the system, ranging from $1 \%$ at the most oligotrophic open ocean sites to near $50 \%$ at eutrophic coastal-estuarine systems. Since then, the vast majority of studies still corroborate this pattern: $\mathrm{BGE}>30 \%$ on average in more productive areas, such as upwelling and estuarine systems (ASMALA et al., 2014; DEL GIORGIO; NEWELL, 2012; FUENTES et al., 2012; GUENTHER et al., 2008), and BGE $<20 \%$ on average at oceanic sites (ALONSO-SÁEZ et al., 2007; DEL GIORGIO et al., 2011; LØNBORG et al., 2013; REINTHALER et al., 2008). This means that in most eutrophic systems, bacterioplankton act more as a source of organic carbon for the higher consumers.

In the present study, we aimed to evaluate the main role of bacterioplankton (i.e., source or sink of organic carbon) in a hypereutrophic tropical estuarine system (Recife harbor, NE Brazil) through simultaneous BP and $\mathrm{BR}$ in situ measurements and BCD and BGE calculation. Despite the high bacterial production, bacterial growth efficiency was low due to high bacterial respiration rates. The role of temperature and nitrogen limitation in the regulation of bacterial carbon metabolism in this system is then discussed.

\section{MATERIAL AND METHODS}

\section{STUDY SITE}

The Recife harbor $\left(08^{\circ} 03^{\prime} \mathrm{S}\right.$; $34^{\circ} 52^{\prime} \mathrm{W}$, Recife - PE, Brazil) is a hypereutrophic well-mixed estuary with high primary production rates (GUENTHER et al., 2015). Situated in a densely populated area of the city, it is supplied by three urban and intensely polluted rivers: the Pina, Capibaribe and Beberibe. It is a long, narrow and shallow system (7 km long, 250-1000 m wide and 1-12 m deep) connected to the ocean by a $300 \mathrm{~m}$ wide mouth, and also influenced by the marine spray crossing the long ( 4 $\mathrm{km})$ and thin $(30 \mathrm{~m})$ beach rock reef that separates it from the ocean (Fig. 1). Tides are semidiurnal with maximum ranges of $2.3 \mathrm{~m}$. Tidal currents are strong $\left(30 \mathrm{~cm} \mathrm{~s}^{-1}\right.$ on average), leading to residence times of 5-9 $\mathrm{h}$, shorter than a complete tidal cycle (GUENTHER et al., 2015). The local climate is tropical humid with dry summers and wet winters (KÖPPEN, 1900). 


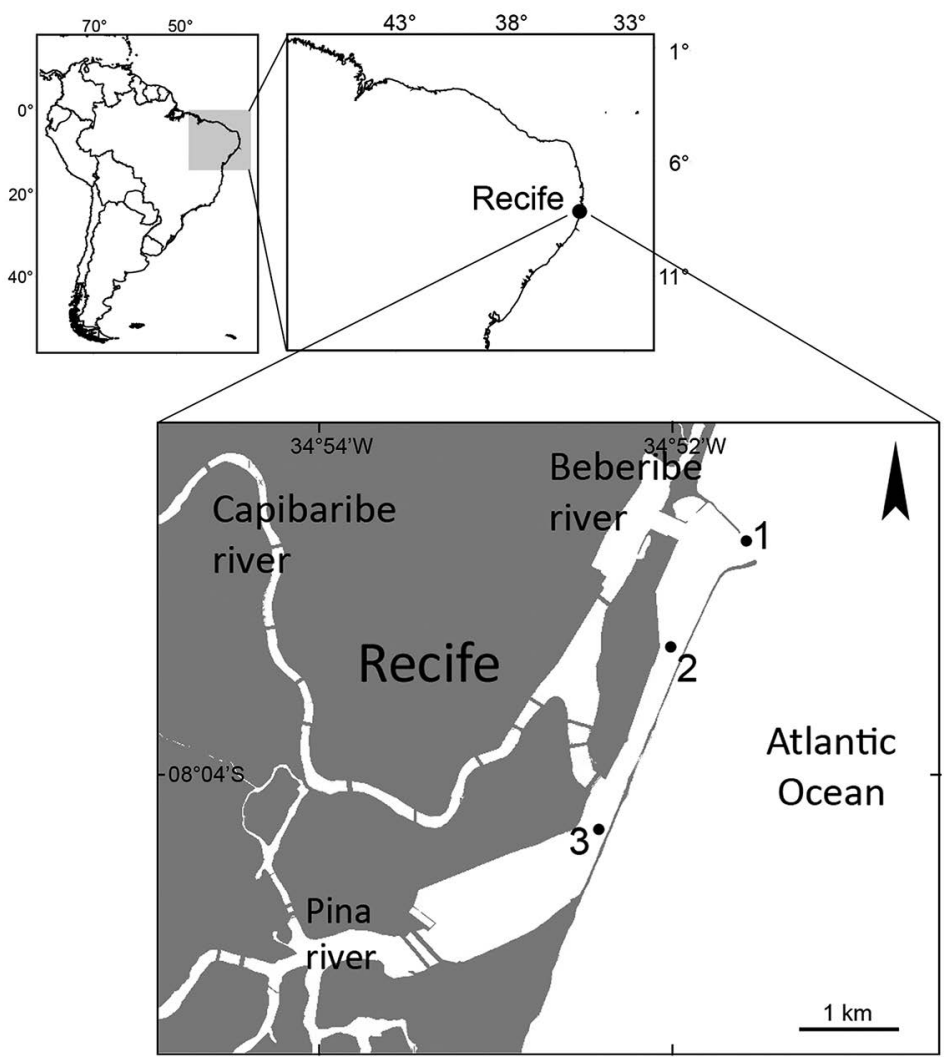

Figure 1. Map of the Recife harbor, located at the city of Recife - PE, northeastern coast of Brazil, showing its major rivers and the three sampling stations.

\section{EXPERIMENTAL DESIGN AND SAMPLE ANALYSES}

The samplings were performed at three stations located at distinct sections of the estuary: \#1 - outer (12 $\mathrm{m}$ deep), \#2 - middle ( $9 \mathrm{~m}$ deep) and \#3 - inner (3 $\mathrm{m}$ deep) (Fig. 1), during both ebb and flood tides, every 3 months during a year (January, April, July and October, 2008). The months sampled represent the wet (April and July) and dry (October and January) seasons (see GUENTHER et al., 2015). The stations were sampled opposed to the water flow, i.e., from the outer to the inner estuary during the ebb tide and conversely during the flood tide. The water samples were collected with 10L Niskin bottles at the subsurface layer for dissolved inorganic nutrients, dissolved organic carbon (DOC) and dissolved oxygen (DO) contents, $\mathrm{pH}$ and bacterial production (BP) and respiration (BR) incubation experiments. Temperature and salinity were obtained in situ through a portable thermometer and refractometer.

Nutrients, DOC and DO contents of each sample were determined in triplicates (or more when needed) in the laboratory within $1 \mathrm{~h}$ collection following the methods proposed by GRASSHOFF et al. (1983) for ammonium $\left(\mathrm{N}-\mathrm{NH}_{4}\right)$, nitrite $\left(\mathrm{N}^{-\mathrm{NO}_{2}}\right)$, nitrate $\left(\mathrm{N}-\mathrm{NO}_{3}\right)$ and phosphate $\left(\mathrm{P}-\mathrm{PO}_{4}\right)$, STRICKLAND and PARSONS (1972) for DOC, and AMINOT and CHAUSSEPIED (1983) for DO. The pH was measured with a pH meter Gehaka PG2000.

Bacterial production rates were determined through ${ }^{3} \mathrm{H}$-leucine incorporation (SMITH; AZAM, 1992). Samples and controls $(1.3 \mathrm{~mL})$ were incubated in triplicates in $2.0 \mathrm{~mL}$ sterile polypropylene tubes with $\mathrm{L}-\left[4,5-{ }^{3} \mathrm{H}\right]$ leucine at a $10 \mathrm{nM}$ final concentration, based on previous saturation curves. Controls were immediately fixed in 90 


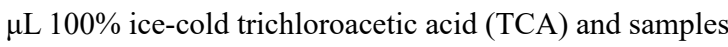
were incubated for $1 \mathrm{~h}$ at room temperature in the dark. Incubation was halted with $90 \mu \mathrm{L} 100 \%$ ice-cold TCA and the isotopic activity of the samples was determined in a Beckman LS6000SC scintillation counter. Bacterial carbon production was calculated using a protein/carbon conversion factor of 0.86 (SIMON; AZAM, 1989).

Bacterial respiration rates were measured through dissolved oxygen consumption in the picoplankton $(<2.0$ $\mathrm{mm}$ ) fraction. Samples were previously filtered through 2.0 $\mathrm{mm}$ polycarbonate membranes and incubated in situ in 150 $\mathrm{mL}$ borosilicate bottles (triplicates) for $24 \mathrm{~h}$. The initial DO concentrations were also determined in triplicate samples immediately fixed with Winkler reagents (manganese sulfide and alkaline iodine). Dissolved oxygen contents of each sample were determined in triplicates following the Winkler's titration method (AMINOT; CHAUSSEPIED, 1983). Bacterial respiration rates were estimated using a respiration quotient (RQ) of 1.0 (BIDDANDA et al., 1994). It is important to note that BR rates include also autotrophic picoplankton respiration.

Bacterial carbon demand (BCD) was calculated as $\mathrm{BP}+\mathrm{BR}$, and bacterial growth efficiency (BGE) as $\mathrm{BP} / \mathrm{BCD}$ (DEL GIORGIO; COLE, 1998). The DOC turnover time through bacterioplankton (day ${ }^{-1}$ ) was estimated as the ratio between the DOC content and the BCD at each sample.

The meteorological conditions and the circulation dynamics of this system during this period have been presented and discussed elsewhere (GUENTHER et al., 2015).

\section{DATA ANALYSES}

For each variable, differences between tidal periods (ebb and flood) and among stations (outer, middle and inner) and months (January, April, July, October) were verified using a Mann-Whitney U test (for two groups: tidal periods) or a Kruskal-Wallis test (for multiple groups: stations and months), as data were not normally distributed (based on KolmogorovSmirnov test). The measured variables were compared through Pearson's correlations.

\section{RESULTS}

\section{ABIOTIC VARIABLES}

Some abiotic variables sampled presented significant seasonal variations (Table 1). Spatial or tidal statistical differences, however, were not observed. Water temperature ranged from $25^{\circ} \mathrm{C}$ to $30^{\circ} \mathrm{C}$, higher in January and April $\left(30^{\circ} \mathrm{C}\right)$ than in July: $25^{\circ} \mathrm{C}(\mathrm{H}=19.5$; $p=0.0002)$, and salinity ranged from 26 to 36 , being slightly lower at the inner (\#3) than the outer (\#1) station, although not statistically different $(\mathrm{H}=4.01 ; p=0.13)$.

Ammonium contents ranged from 0.4 to $5.2 \mu \mathrm{M}$, while the oxidized nitrogen $(\mathrm{N})$ forms $\left(\mathrm{N}-\mathrm{NO}_{2}+\mathrm{N}-\mathrm{NO}_{3}\right)$ ranged from 0.6 to $8.3 \mu \mathrm{M}$. These $\mathrm{N}$ forms constituted the major fraction of total dissolved inorganic nitrogen (DIN): $\mathrm{N}-\mathrm{NO}_{2} / \mathrm{NO}_{3}=62 \%$ of DIN, on average, and $\mathrm{N}-\mathrm{NH}_{4}=38 \%$. Phosphate contents ranged from 0.4 to $12 \mu \mathrm{M}$ and the DIN:DIP ratios varied from 0.8 to 5.7 (Fig. 2). Dissolved organic carbon contents ranged from 475 to $942 \mu \mathrm{M}$. Dissolved oxygen contents ranged from $179-402 \mu \mathrm{M}$ ) and the $\mathrm{pH}$ ranged from 8.0 to 8.5 .

The $\mathrm{N}-\mathrm{NO}_{2} / \mathrm{NO}_{3}$ contents increased from January and April (3.3 $\mu \mathrm{M}$ on average) to July: $6.1 \mu \mathrm{M}(\mathrm{H}=8.23$; $p=0.04)$. The DO contents decreased from April, beginning of the wet season: $262 \mu \mathrm{M}$ (on average), to October, beginning of the dry season: $234 \mu \mathrm{M}$, on average $(\mathrm{H}=11.1$; $p=0.01)$. The $\mathrm{pH}$ also decreased from January $(\mathrm{pH}=8.4)$ to July: $\mathrm{pH}=8.1(\mathrm{H}=12.5 ; p=0.005)$.

\section{BACTERIAL METABOLIC RATES}

Bacterial metabolic rates were highly variable throughout the year studied with no significant differences between tidal phases or among stations or months (Fig. 3). Bacterial production (BP) ranged from 0.03 to $0.4 \mu \mathrm{M} \mathrm{C} \mathrm{h}^{-1}\left(0.24 \mu \mathrm{M} \mathrm{C} \mathrm{h}^{-1}\right.$ on average, $\mathrm{CV}=42 \%$ ), bacterial respiration (BR) ranged from 0.5 to $4.1 \mu \mathrm{M} \mathrm{C} \mathrm{h}^{-1}\left(1.72 \mu \mathrm{M} \mathrm{C} \mathrm{h}^{-1}\right.$ on average, $\left.\mathrm{CV}=58 \%\right)$, bacterial carbon demand $(\mathrm{BCD}=\mathrm{BP}+\mathrm{BR})$ ranged from 0.6 to $4.5 \mu \mathrm{M} \mathrm{C} \mathrm{h}^{-1}\left(1.96 \mu \mathrm{M} \mathrm{C} \mathrm{h}^{-1}\right.$ on average, $\mathrm{CV}=54 \%$ ) and bacterial growth efficiency (BGE=BCD/ $\mathrm{BR}$ ) varied from 2 to $29 \%$ ( $13 \%$ on average, $\mathrm{CV}=47 \%)$. The DOC turnover time through bacterioplankton consumption (DOC/BCD) ranged from 5 to 44 days (20 days on average, $\mathrm{CV}=54 \%$ ).

The correlation matrix of all variables sampled showed that BP and BR rates were directly correlated to each other $(\mathrm{r}=0.58 ; p=0.003)$. The $\mathrm{BP}$ rates were also directly correlated to $\mathrm{N}_{-} \mathrm{NH}_{4}$ contents $(\mathrm{r}=0.53 ; p=0.01)$ and $\mathrm{P}-\mathrm{PO}_{4}$ contents $(\mathrm{r}=0.76 ; p<0.001)$. The $\mathrm{BR}$ rates were directly correlated to $\mathrm{P}_{-} \mathrm{PO}_{4}$ contents $(\mathrm{r}=0.56 ; p=0.004)$ and inversely correlated to $\operatorname{BGE}(\mathrm{r}=-0.46 ; p=0.022)$ (Table 2).

\section{DISCUSSION}

Bacterial carbon metabolism at Recife harbor varied greatly, without a clear tidal, seasonal or spatial pattern. In spite of the high bacterial production, the extreme bacterial 
Table 1. Range and average values (in parentheses) of the abiotic variables at each month sampled. Variables marked with asterisks showed significant variations among months at $\mathrm{p}<0.05(*), \mathrm{p}<0.01(* *)$ and $\mathrm{p}<0.001$ levels $(* * *)$. In these, treatments with the same symbol are not significant different from each other, based on the Kruskal-Wallis test.

\begin{tabular}{lcccc}
\hline & JAN & APR & JUL & OCT \\
\hline Water temperature $\left({ }^{\circ} \mathrm{C}\right)^{* *}$ & $29-30(29)^{\mathrm{a}}$ & $29-30(29)^{\mathrm{a}}$ & $25-25(25)^{\mathrm{b}}$ & $27-28(27)^{\mathrm{a}, \mathrm{b}}$ \\
Salinity & $28-36(33)$ & $26-35(31)$ & $29-33(31)$ & m.d. \\
$\mathrm{DO}(\mu \mathrm{M})^{*}$ & $179-402(256)^{\mathrm{a}, \mathrm{b}}$ & $259-265(262)^{\mathrm{a}}$ & $229-262(243)^{\mathrm{a}, \mathrm{b}}$ & $229-239(234)^{\mathrm{b}}$ \\
$\mathrm{pH}^{* *}$ & $8.3-8.5(8.4)^{\mathrm{a}}$ & $8.2-8.4(8.3)^{\mathrm{a}, \mathrm{b}}$ & $8.0-8.4(8.1)^{\mathrm{b}}$ & $8.0-8.3(8.1)^{\mathrm{a}, \mathrm{b}}$ \\
$\mathrm{NH}_{3}(\mu \mathrm{M})$ & $0.4-5.2(2.3)$ & $0.4-5.0(2.8)$ & $1.0-3.2(2.3)$ & $1.5-2.7(2.1)$ \\
$\mathrm{NO}_{2}+\mathrm{NO}_{3}(\mu \mathrm{M})$ & $1.4-4.8(2.8)^{\mathrm{b}}$ & $1.0-4.8(3.8)^{\mathrm{b}}$ & $4.8-7.3(6.1)^{\mathrm{a}}$ & $0.6-8.3(3.9)^{\mathrm{a}, \mathrm{b}}$ \\
$\mathrm{PO}_{4}(\mu \mathrm{M})$ & $0.9-12(5.8)$ & $1.5-12(6.1)$ & $1.9-5.4(3.9)$ & $0.4-3.1(1.5)$ \\
$\mathrm{DOC}(\mu \mathrm{M})$ & $650-917(769)$ & $675-942(814)$ & $475-892(594)$ & $525-892(713)$ \\
\hline
\end{tabular}

m.d.=missing data.

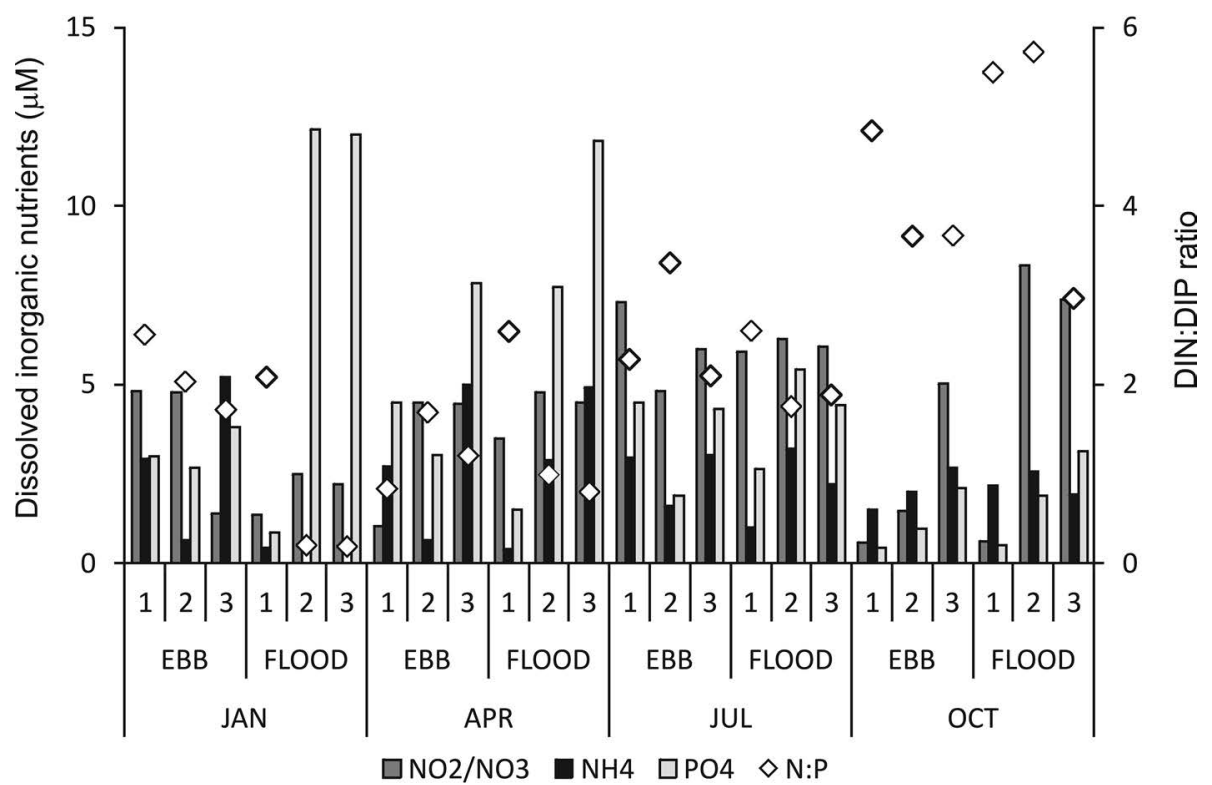

Figure 2. Dissolved inorganic nitrogen $\left(\mathrm{N}-\mathrm{NO}_{3} / \mathrm{NO}_{2}\right.$ and N-NH$\left.{ }_{4}\right)$ and phosphorous $\left(\mathrm{P}-\mathrm{PO}_{4}\right)$ contents and the DIN:DIP ratio (N:P) at the three sampled stations: \#1 (outer), \#2 (middle), \#3 (inner) during ebb and flood tides and the four months sampled: January, April, July and October.

respiration rates led to low bacterial growth efficiencies, indicating that bacterioplankton are acting more as organic material remineralizers than biomass source for the higher trophic levels.

The high variability in $\mathrm{BP}, \mathrm{BR}, \mathrm{BCD}$ and $\mathrm{BGE}$, also observed in other tropical estuaries (GUENTHER et al., 2008; RAM et al., 2007), was already expected due to the high hydrodynamic complexity of this system (GUENTHER et al., 2015). Although the BP rates measured in Recife harbor were similar, on average, to other tropical and temperate estuaries (APPLE; DEL GIORGIO, 2007; DEL GIORGIO; NEWELL, 2012; GUENTHER et al., 2008; RAM et al., 2003), the BR rates were higher, leading to lower BGE (see Table 3). Bacterial respiration rates were more variable than $\mathrm{BP}$ rates and inversely correlated to BGE (see Table 2) which suggest that BGE variations are better explained by BR.

Temperature strongly influences bacterial carbon metabolism (MADIGAN et al., 2010). Warmer conditions enhance metabolic rates (BROWN et al., 2004), which also leads to higher energetic loss (MACLEAN, 2008; PFEIFFER et al., 2001). Therefore, water temperatures are often directly correlated to bacterial production and respiration (JIMENEZ-MERCADO et al., 2007; KIRCHMAN et al., 2005; POMEROY et al., 1995; RAYMOND; BAUER, 2000; SAMPOU; KEMP, 

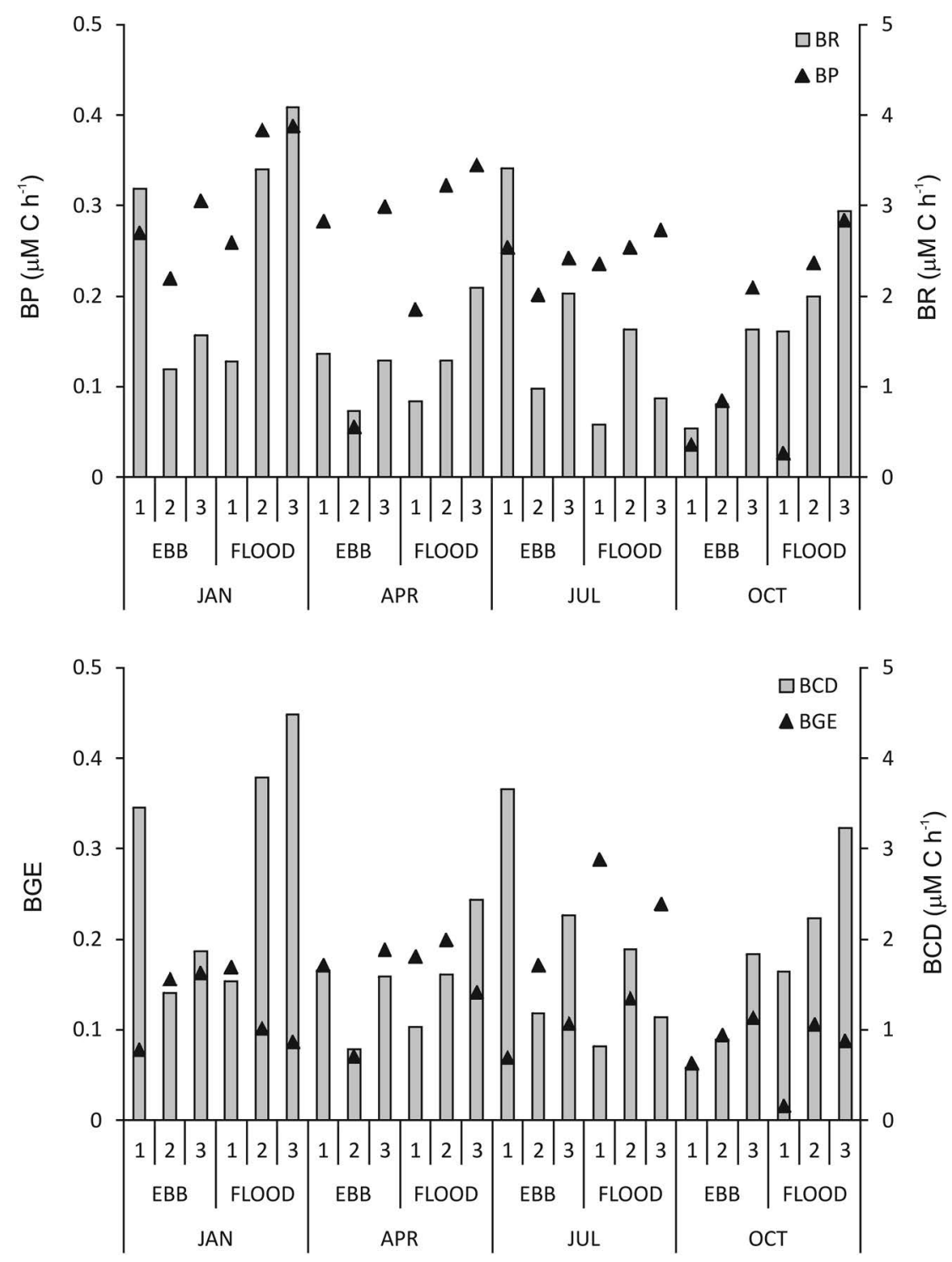

Figure 3. Bacterial production (BP) and respiration (RB) (top panel) and bacterial carbon demand (BCD) and growth efficiency (BGE) (bottom panel) at the three sampled stations: \#1 (outer), \#2 (middle), \#3 (inner) during ebb and flood tides and the four months sampled: January, April, July and October.

1994; SHIAH; DUCKLOW, 1994). When the effects of temperature on BR are higher than on BP due to this increase in energy expenditure, higher temperatures may result in lower BGE (AMADO et al., 2013; APPLE et al., 2006; BERGGREN et al., 2010; GUENTHER et al., 2008; HALL; COTNER, 2007; RIVKIN; LEGENDRE, 2001). Temperatures at Recife harbor are high throughout the year $\left(25-30^{\circ} \mathrm{C}\right)$, which led to high bacterial production but even higher bacterial respiration rates. Indeed, previous studies performed in tropical estuarine waters showed lower BR rates $\left(\mathrm{BR}_{\max }=0.7 \mu \mathrm{M} \mathrm{C} \mathrm{h}^{-1}\right)$ where maximum temperatures were around $25^{\circ} \mathrm{C}$ (GUENTHER et al., 2008) and higher $\mathrm{BR}$ rates $\left(0.7-3.3 \mu \mathrm{M} \mathrm{Ch}^{-1}\right)$ at higher temperature ranges: $27-32^{\circ} \mathrm{C}$ (LEE et al., 2009; RAM et al., 2003).

Nutrient availability also plays a major role in regulating bacterial carbon metabolism (ASMALA et al., 2014; BERGGREN et al., 2010; GASOL et al., 2009; SMITH; KEMP, 2003). Bacterial uptake of DOM follows a rather constant ratio: C:N:P 50:10:1 (FAGERBAKKE et al., 1996; GOLDMAN et al., 1987). When DOM is depleted in N or P, they can balance their stoichiometric requirements by increasing inorganic $\mathrm{N}$ or 
Table 2. Pearson correlation coefficients between the variables sampled and estimated at Recife harbor. Temp=temperature; $\mathrm{Sal}=$ salinity; $\mathrm{DO}=$ dissolved oxygen; $\mathrm{DOC}=$ dissolved organic carbon; $\mathrm{BP}=$ bacterial production; $\mathrm{BR}=$ bacterial respiration; $\mathrm{BGE}=$ bacterial growth efficiency. Asterisks mean significant correlations at $\mathrm{p}<0.05(*), \mathrm{p}<0.01(* *)$ and $\mathrm{p}<0.001$ levels $(* * *)$. Not significant correlations $(\mathrm{p}>0.05)$ are not shown $(-)$.

\begin{tabular}{|c|c|c|c|c|c|c|c|c|c|c|}
\hline & Sal & DO & $\mathrm{pH}$ & $\mathrm{NH}_{4}$ & $\mathrm{NO}_{2} / \mathrm{NO}_{3}$ & $\mathrm{PO}_{4}$ & DOC & $\mathrm{BP}$ & BR & BGE \\
\hline Temp & - & _- & $0.73 * * *$ & - & $-0.45^{*}$ & $0.44 *$ & $0.67 * *$ & - & - & - \\
\hline Sal & & - & - & - & $-0.48^{*}$ & - & - & - & - & - \\
\hline DO & & & - & - & - & - & - & - & - & - \\
\hline $\mathrm{pH}$ & & & & - & $-0.58^{* *}$ & - & - & - & - & - \\
\hline $\mathrm{NH}_{4}$ & & & & & - & $0.69 * * *$ & - & $0.53 *$ & - & - \\
\hline $\mathrm{NO}_{2} / \mathrm{NO}_{3}$ & & & & & & - & - & - & - & - \\
\hline $\mathrm{PO}_{4}$ & & & & & & & - & $0.76^{* * *}$ & $0.56^{* *}$ & - \\
\hline DOC & & & & & & & & - & - & - \\
\hline BP & & & & & & & & & $0.58 * *$ & - \\
\hline $\mathrm{BR}$ & & & & & & & & & & $-0.46^{*}$ \\
\hline
\end{tabular}

Table 3. Mean bacterial production rates (BP), bacterial respiration rates (BR) and bacterial growth efficiency (BGE) from the present study and other tropical and temperate estuarine systems.

\begin{tabular}{lccccc}
\hline References & Region & Site & BP $\left(\mu \mathrm{M} \mathrm{C} \mathrm{h}^{-1}\right)$ & $\mathrm{BR}\left(\mu \mathrm{M} \mathrm{Ch}^{-1}\right)$ & $\mathrm{BGE}$ \\
\hline Present study & Tropical & Recife Harbor (BRA) & 0.24 & 1.72 & $13 \%$ \\
APPLE and DEL GIORGIO, 2007 & Temperate & Monie Bay (USA) & 0.15 & 0.23 & $32 \%$ \\
DEL GIORGIO and NEWELL, & Temperate & Delaware Bay (USA) & 0.12 & 0.52 & $18 \%$ \\
2012 & Tropical & Guanabara Bay (BRA) & 0.20 & 0.25 & $52 \%$ \\
GUENTHER et al., 2008 & Tropical & Zuary Estuary (IND) & 0.21 & 0.95 & $18 \%$ \\
RAM et al., 2003 & & &
\end{tabular}

P uptake (CHURCH, 2008; KIRCHMAN, 1994), which is achieved via the activation of metabolic pathways, raising respiration rates and lowering growth yield and $\mathrm{BGE}$ (HESSEN; ANDERSON, 2008; JANSSON et al., 2006).

At Recife harbor, although we did not measure DON or DOP contents, and thus cannot estimate DOM C:N:P ratios, the low DIN:DIP ratios $(0.8-5.7)$ due to the large $\mathrm{P}_{-} \mathrm{PO}_{4}$ inputs from domestic sewage and agriculture runoff, indicate inorganic nitrogen limitation. Moreover,

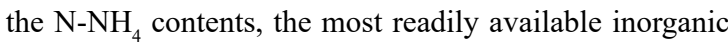
$\mathrm{N}$ form for bacterioplankton $(\mathrm{CHURCH}, 2008$; VALLINO et al., 1996), represented, on average, a minor fraction of total DIN (38\%). Inorganic nitrogen limitation of bacterial production and growth efficiency has been widely reported in both batch cultures and natural systems experiments (CARLSSON et al., 2012; CHURCH et al., 2000; KROER, 1993; ORTEGA-RETUERTA et al., 2012), some of them showing a higher dependency of $\mathrm{BGE}$ on inorganic nitrogen than on DOM quality (ASMALA et al., 2014; LØNBORG et al., 2011). The direct correlation between $\mathrm{BP}$ and $\mathrm{N}_{-} \mathrm{NH}_{4}(\mathrm{r}=0.53 ; p=0.01)$ and the absence of correlation between $\mathrm{BP}$ and the $\mathrm{N}$-oxidized forms $(\mathrm{r}=0.25$; $p=0.23$ ) suggests a higher reliability of bacterioplankton on ammonium contents in this system.

The higher BGE observed in the more productive estuarine systems is usually correlated to the nutrient availability and/or DOM quality (APPLE; DEL GIORGIO, 2007; ASMALA et al., 2014; DEL GIORGIO; NEWELL, 2012; GUENTHER et al., 2008) which support bacterial growth (BP) with less maintenance energy costs (BR). The DOM quality (or lability) is defined by its nutritional value (stoichiometric balanced $\mathrm{C}: \mathrm{N}: \mathrm{P}$ ratio), diagenetic state (freshly leached $v s$. microbial processed), as well as molecular size (low vs. high molecular weight) and shape (degree of aromaticity), irrespective of its allochthonous or autochthonous origin (AMON; BENNER, 1996; ATTERMEYER et al., 2014; GOLDMAN et al., 1987). The relatively rapid estimated DOC turnover through bacterioplankton consumption at Recife harbor, from a few days to a little more than a month ( 5 to 44 days), suggests that the DOM content range from labile to semi labile (CARLSON, 2002).

Phytoplankton-derived DOM represents an important labile source for bacterioplankton supporting high bacterial 
growth in both batch-cultures and mesocosms experiments (BELL; SAKSHAUG, 1980; CHERRIER et al., 1996; CHRZANOWSKI; HUBBARD, 1989). At Recife harbor a considerable amount of phytoplankton exudates is expected due to the high primary production rates (GUENTHER et al., 2015). Moreover, the high domestic sewage input at this system can be even more labile for bacterial growth than autochthonous phytoplankton-derived DOM (XU et al., 2013; XU et al., 2014). Thus, it is possible that despite the high nutrient input and supposed labile to semi labile DOM contents, the low DIN:DIP ratios are hindering BGE through increasing BR at Recife harbor. Future research should thus focus on DOM stoichiometry and chemical composition along with bacterial uptake experiments to quantify the major available DOM sources in this system and verify the hypothesis of inorganic nitrogen limitation of bacterial growth raised in the present study.

\section{CONCLUSIONS}

The high temperatures and the inorganic nitrogen limitation due to large allochthonous $\mathrm{P}-\mathrm{PO}_{4}$ loadings are the main factors driving the high $\mathrm{BR}$ rates and, hence, the low BGE observed at Recife harbor, in spite of the high primary productivity. These results highlight the importance of increasing in situ BP and BR estimates in eutrophic tropical estuaries, in order to reevaluate the established direct correlation between BGE and productivity based mostly on temperate systems.

The high bacterial carbon demand and the relatively rapid DOC turnover indicate that huge amounts of DOM are channeled through bacterioplankton, showing the importance of this compartment in organic material recycling at this hypereutrophic system. The low BGE, however, means that most of this up taken DOM is released as inorganic nutrients and $\mathrm{CO}_{2}$ to the water column. The high bacterial production, similar to other tropical and temperate estuarine systems, suggests that this compartment also plays an important role as biomass sources for the next trophic levels (BONG; LEE, 2011; TROUSSELLIER et al., 2005; VAN DEN MEERSCHE et al., 2011), but its major role in this system is as DOM remineralizer. The large allochthonous nutrient inputs along with the rapid DOM remineralization, supports the high primary productivity and biomass of the system (GUENTHER et al., 2015), which is the main source for the plankton consumers.

\section{ACKNOWLEDGEMENTS}

This work was supported by the National Research Council (CNPq - 470481/2005-4); and the Pernambuco State Research Foundation (FACEPE - APQ-01991.08/06, APQ-0120-1.08/07, APQ-0285-1.08/06, BFP-0023-1.08/06 to M.G). We are grateful to several undergraduate and graduate students and technicians from Laboratório de Zooplâncton, Laboratório de Oceanografia Química, Laboratório de Oceanografia Física Estuarina e Costeira (Departamento de Oceanografia - Universidade Federal de Pernambuco - DOCEAN/UFPE) and Instituto de Estudos do Mar Almirante Paulo Moreira (IEAPM) for laboratory and field support, and to the reviewers for important suggestions that improved the quality of our manuscript.

\section{REFERENCES}

ALONSO-SÁEZ, L.; GASOL, J. M.; ARÍSTEGUI, J.; VILAS, J. C.; VAQUÉ, D.; DUARTE, C. M.; AGUSTÍ, S. Large-scale variability in surface bacterial carbon demand and growth efficiency in the subtropical northeast Atlantic Ocean. Limnol. Oceanogr., v. 52, n. 2, p. 533-546, 2007.

AMADO, A. M.; MEIRELLES-PEREIRA, F.; VIDAL, L. O.; SARMENTO, H.; SUHETT, A. L.; FARJALLA, V. F.; COTNER, J. B.; ROLAND, F. Tropical freshwater ecosystems have lower bacterial growth efficiency than temperate ones. Front. Microbiol., v. 4, p. 167, 2013.

AMINOT, A.; CHAUSSEPIED, M. Manuel des analyses chimiques en milieu marin. Brest: Centre National pour l'Exploitation des Océans, 1983. $395 \mathrm{p}$.

AMON, R. M. W.; BENNER, R. Bacterial utilization of different size classes of dissolved organic matter. Limnol Oceanogr., v. 41, n. 1, p. 41-51, 1996.

APPLE, J. K.; DEL GIORGIO, P. A. Organic substrate quality as the link between bacterioplankton carbon demand and growth efficiency in a temperate salt-marsh estuary. Isme J., v. 1, n. 8 , p. 729-742, 2007.

APPLE, J. K.; DEL GIORGIO, P. A.; KEMP, W. M. Temperature regulation of bacterial production, respiration, and growth efficiency in a temperate salt-marsh estuary. Aquat. Microb. Ecol., v. 43, n. 3, p. 243-254, 2006.

ASMALA, E.; AUTIO, R.; KAARTOKALLIO, H.; PITKÄNEN, L.; STEDMON, C. A.; THOMAS, D. N. Bioavailability of riverine dissolved organic matter in three Baltic Sea estuaries and the effect of catchment land use. Biogeosciences, v. 10, n. 11, p. 6969-6986, 2014.

ATTERMEYER, K.; HORNICK, T.; KAYLER, Z. E.; BAHR, A.; ZWIRNMANN, E.; GROSSART, H. P.; PREMKE, K. Enhanced bacterial decomposition with increasing addition of autochthonous to allochthonous carbon without any effect on bacterial community composition. Biogeosciences, v. 11, n. 6, p. $1479-1489,2014$. 
BARRERA-ALBA, J. J.; GIANESELLA, S. M. F.; MOSER, G. A. O.; SALDANHA-CORREA, F. M. P. Bacterial and phytoplankton dynamics in a sub-tropical estuary. Hydrobiologia, v. 598, n. 1, p. 229-246, 2008.

BELL, W. H.; SAKSHAUG, E. Bacterial utilization of algal extracellular products. 2. A kinetic-study of natural-populations. Limnol. Oceanogr., v. 25, n. 6, p. 1021-1033, 1980.

BERGGREN, M.; LAUDON, H.; JONSSON, A.; JANSSON, M. Nutrient constraints on metabolism affect the temperature regulation of aquatic bacterial growth efficiency. Microb. Ecol., v. 60, n. 4 , p. 894-902, 2010.

BIDDANDA, B.; OPSAHL, S.; BENNER, R. Plankton respiration and carbon flux through bacterioplankton on the Louisiana Shelf. Limnol. Oceanogr., v. 39, n. 6, p. 1259-1275, 1994.

BONG, C. W.; LEE, C. W. The contribution of heterotrophic nanoflagellate grazing towards bacterial mortality in tropical waters: comparing estuaries and coastal ecosystems. Mar. Freshw. Res., v. 62, n. 4, p. 414-420, 2011.

BROWN, J. H.; GILLOOLY, J. F.; ALLEN, A. P.; SAVAGE, V. M.; WEST, G. B. Toward a metabolic theory of ecology. Ecology, v. 85, n. 7, p. 1771-1789, 2004.

CARLSON, C. A. Production and removal processes. In: HANSELL, D. A.; CARLSON, C. A. (Eds.). Biogeochemistry of Marine Dissolved Organic Matter. San Diego: Academic Press, 2002. p. 91-150.

CARLSSON, P.; GRANÉLI, E.; GRANÉLI, W.; RODRIGUEZ, E. G.; CARVALHO, W. F.; BRUTEMARK, A.; LINDEHOFF, E. Bacterial and phytoplankton nutrient limitation in tropical marine waters, and a coastal lake in Brazil. J. Exp. Mar. Biol. Ecol., v. 418-419, p. 37-45, 2012.

CHERRIER, J.; BAUER, J. E.; DRUFFEL, E. R. M. Utilization and turnover of labile dissolved organic matter by bacterial heterotrophs in eastern north Pacific surface waters. Mar. Ecol. Prog. Ser., v. 139, p. 267-279, 1996.

CHRZANOWSKI, T. H.; HUBBARD, J. G. Bacterial utilization of algal extracellular products in a southwestern reservoir. Hydrobiologia, v. 179, n. 1, p. 61-71, 1989.

CHURCH, M. J. Resource control of bacterial dynamics in the sea. In: KIRCHMAN, D. L. Microbial Ecology of the Oceans. $2^{\text {nd }}$ ed. New Jersey: John Wiley \& Sons, 2008. p. 335-382.

CHURCH, M. J.; HUTCHINS, D. A.; DUCKLOW, H. W. Limitation of bacterial growth by dissolved organic matter and iron in the Southern Ocean. Appl. Environ. Microbiol., v. 66, n. 2, p. $455-466,2000$.

CORY, R. M.; MCNEILL, K.; COTNER, J. P.; AMADO, A.; PURCELL, J. M.; MARSHALL, A. G. Singlet oxygen in the coupled photochemical and biochemical oxidation of dissolved organic matter. Environ. Sci. Technol., v. 44, n. 10, p. 3683$3689,2010$.

DAY JR, J. W.; CRUMP, B. C.; KEMP, W. M.; YÁÑEZ-ARANCIBIA, A. Estuarine Ecology. $2^{\text {nd }}$ ed. New York: Wiley-Blackwell, 2013.

DEL GIORGIO, P. A.; COLE, J. J. Bacterial growth efficiency in natural aquatic systems. Annu. Rev. Ecol. Syst., v. 29, p. 503$541,1998$.

DEL GIORGIO, P. A.; CONDON, R.; BOUVIER, T.; LONGNECKER, K.; BOUVIER, C.; SHERR, E.; GASOL, J. M. Coherent patterns in bacterial growth, growth efficiency, and leucine metabolism along a northeastern Pacific inshore-offshore transect. Limnol. Oceanogr., v. 56, n. 1, p. 1-16, 2011.
DEL GIORGIO, P. A.; NEWELL, R. E. I. Phosphorus and DOC availability influence the partitioning between bacterioplankton production and respiration in tidal marsh ecosystems. Environ. Microbiol., v. 14, n. 5, p. 1296-1307, 2012.

FAGERBAKKE, K. M.; HELDAL, M.; NORLAND, S. Content of carbon, nitrogen, oxygen, sulfur and phosphorus in native aquatic and cultured bacteria. Aquat. Microb. Ecol., v. 10, n. 1, p. 15-27, 1996.

FUENTES, M.; ESCRIBANO, R.; CUEVAS, L. A. Bacterial response to a weak $2006 \mathrm{El}$ Niño condition in an upwelling area of the Humboldt Current System. J. Mar. Biol. Assoc. U.K., v. 92, n. 1, 1-12, 2012.

GASOL, J. M.; PINHASSI, J.; ALONSO-SÁEZ, L.; DUCKLOW, H.; HERNDL, G. J.; KOBLIZEK, M.; LABRENZ, M.; LUO, Y.; MORÁN, X. A. G.; REINTHALER, T.; SIMON, M. Towards a better understanding of microbial carbon flux in the sea. Aquat. Microb. Ecol., v. 53, n. 1, p. 21-38, 2008.

GASOL, J. M.; VÁZQUEZ-DOMÍNGUEZ, E.; VAQUÉ, D.; AGUSTÍ, S.; DUARTE, C. M. Bacterial activity and diffusive nutrient supply in the oligotrophic Central Atlantic Ocean. Aquat. Microb. Ecol., v. 56, n. 1, p. 1-12, 2009.

GAULKE, A. K.; WETZ, M. S.; PAERL, H. W. Picophytoplankton: A major contributor to planktonic biomass and primary production in a eutrophic, river-dominated estuary. Estuar. Coast. Shelf Sci., v. 90, n. 1, p. 45-54, 2010.

GOLDMAN, J. C.; CARON, D. A.; DENNETT, M. R. Regulation of gross growth efficiency and ammonium regeneration in bacteria by substrate C: $\mathrm{N}$ ratio. Limnol. Oceanogr., v. 32, n. 6, p. 1239-1252, 1987.

GRASSHOFF, K. A.; EHRHARDT, M.; KREMLING, K. Methods for seawater analysis. Weinheim: Verlag Chemie, 1983.

GUENTHER, M.; ARAÚJO, M.; FLORES-MONTES, M.; GONZALEZ-RODRIGUEZ, E.; NEUMANN-LEITÃO, S. Eutrophication effects on phytoplankton size-fractioned biomass and production at a tropical estuary. Mar. Pollut. Bull., v. 91, n. 2, p. 537-547, 2015 .

GUENTHER, M.; PARANHOS, R.; REZENDE, C. E.; GONZALEZ-RODRIGUEZ, E.; VALENTIN, J. L. Dynamics of bacterial carbon metabolism at the entrance of a tropical eutrophic bay influenced by tidal oscillation. Aquat. Microb. Ecol., v. 50, n. 2, p. 123-133, 2008a.

GUENTHER, M.; VALENTIN, J. L. Bacterial and phytoplankton production in two coastal systems influenced by distinct eutrophication processes. Oecol Bras., v. 12, n. 1, p. 172-178, 2008b.

HALL, E. K.; COTNER, J. B. Interactive effect of temperature and resources on carbon cycling by freshwater bacterioplankton communities. Aquat. Microb. Ecol., v. 49, n. 1, p. 35-45, 2007.

HESSEN, D. O.; ANDERSON, T. R. Excess carbon in aquatic organisms and ecosystems: Physiological, ecological, and evolutionary implications. Limnol. Oceanogr., v. 53, n. 4, p. 1685-1696, 2008

JANSSON, M.; BERGSTRÖM, A. K.; LYMER, D.; VREDE, K.; KARLSSON, J. Bacterioplankton growth and nutrient use efficiencies under variable organic carbon and inorganic phosphorus ratios. Microb. Ecol., v. 52, n. 2, p. 358-364, 2006.

JIMENÉZ-MERCADO, A.; CAJAL-MEDRANO, R.; MASKE, $\mathrm{H}$. Marine heterotrophic bacteria in continuous culture, the bacterial carbon growth efficiency, and mineralization at excess substrate and different temperatures. Microb. Ecol., v. 54, n. 1, p. 56-64, 2007. 
KIRCHMAN, D. L. The uptake of inorganic nutrients by heterotrophic bacteria. Microb. Ecol., v. 28, n. 2, p. 255-271, 1994.

KIRCHMAN, D. L.; MALMSTROM, R. R.; COTTRELL, M. T. Control of bacterial growth by temperature and organic matter in the Western Arctic. Deep Sea Res. Part II: Top. Stud. Oceanogr., v. 52, n. 24-26, p. 3386-3395, 2005.

KÖPPEN, W. Versuch einer Klassifikation der Klimate, vorzugsweise nach ihren Beziehungen zur Pflanzenwelt. Geogr. Zeits., v. 6, n. 11, p. 593-611, 1900.

KROER, N. Bacterial-growth efficiency on natural dissolved organic-matter. Limnol. Oceanogr., v. 38, n. 6, p. 1282-1290, 1993.

LEE, C. W.; BONG, C. W.; HII, Y. S. Temporal variation of bacterial respiration and growth efficiency in tropical coastal waters. Appl. Environ. Microbiol., v. 75, n. 24, p. 7594-7601, 2009.

LØNBORG, C.; MARTÍNEZ-GARCÍA, S.; TEIRA, E.; ÁLVAREZ-SALGADO, X. A. Bacterial carbon demand and growth efficiency in a coastal upwelling system. Aquat. Microb. Ecol., v. 63, n. 2, p. 183-191, 2011.

LØNBORG, C.; MARTÍNEZ-GARCÍA, S.; TEIRA, E.; ÁLVAREZ-SALGADO, X. A. Effects of the photochemical transformation of dissolved organic matter on bacterial physiology and diversity in a coastal system. Estuar. Coast. Shelf Sci., v. 129, p. 11-18, 2013.

MACLEAN, R. C. The tragedy of the commons in microbial populations: insights from theoretical, comparative and experimental studies. Heredity (Edinb), v. 100, n. 5, p. 471-477, 2008.

MADIGAN, M. T.; MARTINKO, J. M.; STAHL, D.; CLARK, D. P. Brock Biology of Microorganisms. $13^{\text {th }}$ ed. San Francisco: Benjamin Cummings, 2010.

MORTAZAVI, B.; RIGGS, A. A.; CAFFREY, J. M.; GENET, H.; PHIPPS, S. W. The Contribution of Benthic Nutrient Regeneration to Primary Production in a Shallow Eutrophic Estuary, Weeks Bay, Alabama. Estuar. Coast., v. 35, n. 3, p. 862-877, 2012.

ORTEGA-RETUERTA, E.; JEFFREY, W. H.; GHIGLIONE, J. F.; JOUX, F. Evidence of heterotrophic prokaryotic activity limitation by nitrogen in the Western Arctic Ocean during summer. Polar Biol., v. 35, n. 5, p. 785-794, 2012.

PFEIFFER, T.; SCHUSTER, S.; BONHOEFFER, S. Cooperation and competition in the evolution of ATP-producing pathways. Science, v. 292, n. 5516, p. 504-507, 2001.

POMEROY, L. R.; SHELDON, J. E.; SHELDON, W. M.; PETERS, F. Limits to growth and respiration of bacterioplankton in the Gulf of Mexico. Mar. Ecol. Prog. Ser., v. 117, n. 1-3, p. 259-268, 1995.

RAM, A. S. P.; NAIR, S.; CHANDRAMOHAN, D. Bacterial Growth Efficiency in the Tropical Estuarine and Coastal Waters of Goa, Southwest Coast of India. Microb. Ecol., v. 45, n. 1, p. 88-96. 2003.

RAM, A. S. P.; NAIR, S.; CHANDRAMOHAN, D. Bacterial growth efficiency in a tropical estuary: Seasonal variability subsidized by allochthonous carbon. Microb. Ecol., v. 53, n. 4, p. 591-599, 2007.

RAYMOND, P. A.; BAUER, J. E. Bacterial consumption of DOC during transport through a temperate estuary. Aquat. Microb. Ecol., v. 22, n. 1, p. 1-12, 2000.
REINTHALER, T.; SINTES, E.; HERNDL, G. J. Dissolved organic matter and bacterial production and respiration in the sea-surface microlayer of the open Atlantic and the western Mediterranean Sea. Limnol. Oceanogr., v. 53, n. 1, p. 122136, 2008.

RIVKIN, R. B.; LEGENDRE, L. Biogenic carbon cycling in the upper ocean: effects of microbial respiration. Science, v. 291, n. 5512, p. 2398-2400, 2001.

SAMPOU, P.; KEMP, W. M. Factors regulating plankton community respiration in Chesapeake bay. Mar. Ecol. Prog. Ser., v. 110, p. 249-258, 1994.

SCHUMANN, R.; RIELING, T.; GÖRS, S.; HAMMER, A.; SELIG, U.; SCHIEWER, U. Viability of bacteria from different aquatic habitats. I. Environmental conditions and productivity. Aquat. Microb. Ecol., v. 32, n. 2, p. 121-135, 2003.

SHIAH, F. K.; DUCKLOW, H. W. Temperature and substrate regulation of bacterial abundance, production and specific growth rate in Chesapeake Bay, USA. Mar. Ecol. Prog. Ser., v. 103, p. 297-308, 1994.

SIMON, M.; AZAM, F. Protein-content and protein-synthesis rates of planktonic marine-bacteria. Mar. Ecol. Prog. Ser., v. 51, p. 201-213, 1989.

SMITH, D. C.; AZAM, F. A simple, economical method for measuring bacterial protein synthesis rates in seawater using ${ }^{3} \mathrm{H}-$ -leucine. Mar. Microb. food webs, v. 6, n. 2, p. 107-114, 1992.

SMITH, E. M.; KEMP, W. M. Planktonic and bacterial respiration along an estuarine gradient: responses to carbon and nutrient enrichment. Aquat. Microb. Ecol., v. 30, n. 3, p. 251-261, 2003.

STRICKLAND, J. D. H.; PARSONS, T. A Practical Handbook of Seawater Analysis. Ottawa: Fisheries Research Board of Canada. v. 167, 1972. 311 p.

TROUSSELLIER, M.; GOT, P.; MBOUP, M.; CORBIN, D.; GIULIANO, L.; CAPPELLO, S.; BOUVY, M. Daily bacterioplankton dynamics in a sub-Saharan estuary (Senegal River, West Africa): a mesocosm study. Aquat. Microb. Ecol., v. 40, n. 1, p. 13-24, 2005.

VALLINO, J. J.; HOPKINSON, C. S.; HOBBIE, J. E. Modeling bacterial utilization of dissolved organic matter: Optimization replaces Monod growth kinetics. Limnol. Oceanogr., v. 41, n. 8, p. 1591-1609, 1990.

VAN DEN MEERSCHE, K.; SOETAERT, K.; MIDDELBURG, J. J. Plankton dynamics in an estuarine plume: a mesocosm ${ }^{13} \mathrm{C}$ and ${ }^{15} \mathrm{~N}$ tracer study. Mar. Ecol. Progr. Ser., v. 429, p. 2943, 2011

XU, J.; JING, H.; KONG, L.; SUN, M.; HARRISON, P. J.; LIU, $\mathrm{H}$. Effect of seawater-sewage cross-transplants on bacterial metabolism and diversity. Microb. Ecol., v. 66, n. 1, p. 60-72, 2013.

XU, J.; SUN, M. M.; SHI, Z.; HARRISON, P. J.; LIU, H. B. Response of bacterial metabolic activity to riverine dissolved organic carbon and exogenous viruses in estuarine and coastal waters: implications for $\mathrm{CO}_{2}$ emission. Plos $O N E$, v. 9, n. 7, p. e102490, 2014.

YUAN, X.; YIN, K.; HARRISON, P. J.; CAI, W. J.; HE, L.; XU, $\mathrm{J}$. Bacterial production and respiration in subtropical Hong Kong waters: influence of the Pearl River discharge and sewage effluent. Aquat. Microb. Ecol., v. 58, n. 2, p. 167-179, 2010 . 